FORUM

What makes our projects anthropological?

Edited by

Gavin Smith 


\title{
Culture and praxis in post-modern times
}

\author{
Kirk Dombrowski
}

My latest project examines how small-scale, rural village-level sustainability both depends on and at the same time acts against simple household reproduction. That is, I am interested in how "making a community" and "making a family" come to find themselves in opposition, such that "successful" communities continue to shed significant numbers of people, even during economically and politically "good times". The research for this project takes place in Labrador, Canada, in predominantly Inuit coastal villages and neighboring, not-predominantly-Aboriginal cities. Since the 1960s, coastal villages have seen considerable numbers of residents leave. At the conclusion of the most recent land settlement, one-third of Labrador's Inuit population was living in Goose Bay, site of a large NATO air base created during World War II, where they make up more than one-fifth of the total population. If other nearby cities are included-St. John's in Newfoundland, Halifax in Nova Scotia, or Quebec City and Montreal in Quebec Province-more than half of the Labrador Inuit now live somewhere other than the villages with which they most closely identify.

In many ways this project has all the hallmarks of conventional anthropological research. It deals primarily with small-scale societies and Indigenous peoples at the edge of large state processes. Ethnographically speaking, the Labrador Inuit are no more or less "acculturated" to Western lifeways than most of the indigenous peoples that anthropology has encountered in the past and still encounters today. They speak the language of their incorporating state (English), but retain high levels of fluency in the indigenous language of the region (Inuktitut). The villages in questions were formed around centers of mercantile extraction, but have remained predominantly indigenous in population and organization. They deal, collectively and governmentally with corporations whose primary aims amount to little more than large-scale resource extraction, but they continue to depend heavily on self-produced foods-the so-called "country foods" of rural life, such as caribou meat and fish. Yet none of this makes the project anthropological.

\section{The ins and outs of culture}

Questions of disciplinarity are notoriously slippery, particularly in anthropology, which has never had much theoretical or methodological coherence. Paradigmatic moments - those times when one could find candidate theories seeking to unite the disparate method and canon of the field-have actually been quite unusual (the last, arguably, being the short-lived but broad evolutionism of Sherwood Washburn and the integrated evolutionism, ethnography, and archaeology of the larger Harvard-based projects it spawned).

Looked at historically, however, such moments are rare, and for most of the twentieth- 
century anthropology has lacked such orienting theories and depended instead on a common language of mixed methods and what Gregory Bateson (1972) called "middle range" theoretical constructs. The latter are orienting ideas about how to interpret the things we see in the field-typological rather than fully explanatory theories aimed more at saying what things are rather than what they do or how they come to be such as they are. Terms like meaning, institution, symbol, or ethnography are obvious examples. For much disciplinary history, it is the finite range of these guiding ideas that has given anthropology a recognizable and distinctive shape. This distinctiveness has lacked an essence, to be sure, and the particular methods and concepts that make it up have changed over time. Yet taken together, the methods and middlerange theories of anthropology bear what Ludwig Wittgenstein referred to as a "family resemblance" to one another, a recognizable aspect accreted over time by repeated use and moments of piecemeal integration. It is this that, most of the time, passes for anthropological theory.

The porousness of the configuration is apparent to anyone, however, and many of the elements of anthropological theory remain current outside of the discipline. This creates problems for anthropology as extra-academic uses brush uncomfortably up against their evolving place in academic discourse. Yet more is at stake than a lag between production and consumption. Anthropological terms outside the academy both draw importance from their theoretical associations, and simultaneously drag the larger edifice of anthropological knowledge production into pragmatic and problematic situations.

Because this project is concerned with indigenous issues, land claims, development, and money, what makes the project anthropological is its ongoing concern with one of those middle range concepts whose life outside of anthropology has grown increasingly problematic, important, and convoluted: namely culture. It goes without saying that at one time, culture signified a mainstay of anthropological theory-though the general messiness of the term and its lack of conceptual clarity have made it suspect to many current practitioners. But the term lives on and for indigenous peoples, and it has grown in significance as the prospect of land claims and various forms of local autonomy have become more possible. In indigenous Labrador, it is central.

In simple terms, culture has become a critical point of concern for indigenous people(s) for largely pragmatic reasons-its importance drawn from the centrality of the concept to the legal standing of those involved (see Dombrowski 2002; Sider 2003). Without exaggeration, everywhere there are laws about the distinctive legal standing of indigenous peoples-and everywhere indigenous people or surrounding states would implement such laws-the success of local claims to property and participation often turns on the cultural distinctiveness of the people in question (Clifford 1988; Povinelli 2002). In this way, both what people mean when they talk about culture and what any particular resulting culture is seen to entail or claim are both matters of concrete (though often ambiguous) material concern, to people for whom material considerations (like day to day survival) have to take precedence.

Because anthropologists have been intertwined in the sorts of knowledge production that weighs so heavily on such questions, indigenous peoples must necessarily incorporate and confront both their own ethnography, and the history of a discipline whose main assumptions have often been incorporated into the laws, stereotypes, and counterclaims they must overturn. Often, ironically, they hire anthropologists to help them with this, creating a decidedly ambiguous position for those researchers. To be of use, contemporary anthropological research must both draw on and validate past ethnography while attempting to disown the way anthropology has been incorporated into past governing laws and legal standards, and often the discipline's own claims to transparent empiricism and cultural translation. ${ }^{1}$

It is in this pragmatic way that culture remains most relevant to the study of indigenous Labrador. It is because the term itself has currency that it remains central to peoples' engagements with anthropology past and present. But 
like all currencies, culture often now trades on its fungibility. It was, after all, the discovery of large nickel deposits that prompted the recent, large-scale land settlement and the creation of yet another quasi-autonomous indigenous polity in Labrador-Nunatsiavut (Dombrowski 2008). Yet this situation is decidedly common for indigenous peoples these days, where land claims mix with history, development, and poverty, such that culture comes to dominate social research among them for largely pragmatic reasons. This importance trickles down from the most general sorts of claims (that "we" are a particular people with claims on a particular place) to research on the most ordinary elements of social life-the traditions and stories, the social organizations and engagements with the surrounding ecology, the histories of material use, a sense of place, distinct individual/collective subjectivities, and local economies of exchangeall of which have been part of anthropological theories of culture for nearly a century. All of these things played a role in the land claims process in Labrador. And all have been invoked as critical development concerns by the incoming industry (like Vale Inco, the Brazilian mining firm most active in Labrador), surrounding states (such as the Government of Canada), the newly created indigenous bodies formed largely in the negotiation process itself (in this case, the Nunatsiavut Government). In this way, any current anthropology of the region must confront anthropologies of the past, not simply those local to a region but rather the entire disciplinary project, so much of which has been absorbed and incorporated into contemporary development processes and, yet, which must also furnish the means for countering and incorporating those laws and processes.

\section{The long reach of Parsons}

The compromised nature of this situation has recently become the subject of a series of works, each of which is extremely critical of anthropology's complicity in what the authors see as the highly suspect arena of land and rights claims, including works by Kuper (2005), Sutton (2009), and Widdowson and Howard (2008). These authors offer a version of ethnographic truth-telling aimed at showing the dishonesty of the claims process and the way in which anthropologists - and the notions they continue to advocate, even while they distance themselves from them as actual tools of analysis-have become raving innocents amid high stakes games of representation and compromise. Anthropologists, they claim, have given up on any hope for methodological and conceptual clarity in the interest of local political projects, and in the process allowed others to hide more clearly political and self-serving claims behind the mask of ethnographic and ethno-historical obscurity.

Each of these works has sparked controversy, but counterargument has mostly taken the form of counteraccusation. Few have taken up the challenge, however, of saying just how anthropological ideas might be rescued from a mess. One counterapproach is to claim - as Michael Fischer (2007) does-that anthropology needs to recapture the radicalness that culture once represented. This approach sees culture as a (largely ambiguous and therefore flexible) alternative to reigning social theories of economic/ market determinism that have increasing to come to represent political practice in anthropology's traditional research areas. ${ }^{2}$ Fischer writes: "Without a differentiated and relational notion of the cultural (the arts, media, styles, religions, valueorientations, ideologies, imaginaries, worldviews, soul, and the like), the social sciences would be crippled, reducing social action to notions of pure instrumentality" (2007: 1).

It is this alterity, its potential and actual working out, that makes culture a central idea for alternative forms of development and social integration at the periphery, and has been a central element is some efforts to critique (Povinelli 2002) and revitalize the anthropological canon (Graeber 2001).

Yet the view of culture invoked by Fischer, Graeber, and others-culture as coverall for the wellsprings of alterity- is actually not without long-established (and establishment) precedent, which may go a long way to explaining its om- 
nipresence in indigenous contexts even at a time when it is being abandoned by anthropology as a whole. During even the earliest years of Parsonian social sciences, culture represented a self-evident division of social life-the conceptual, the meaningful, the organizational, the symbolic-over which anthropology was given charge, and around which anthropological methodologies and theories might be organized (Parsons 1937). ${ }^{3}$

In the end, the easy acceptance of that role, however, proved problematic for anthropological theory. Although anthropologists took to the Parsonian division earnestly, their approach was by no means critical, and little of the selfevidentiality of who and what was to be considered "primitive" was ever raised. ${ }^{4}$ Anthropologists asked few questions about what constituted the anthropological purview; that is, how the stuff of culture came to be such. This left radical formulations of culture up to those outside both left-leaning anthropology and anthropology in general. The result, at least since the late 1960 s, is that attention to the cultural has come to signify a distinct sort of intellectual endeavor to be found largely outside of anthropology. Here I mean to refer to the rise of cultural studies, in the larger sense that includes such discourses as "post structuralism" (Barthes, Kristeva, Derrida, Foucault; see Barry 2002), "postmodernism" (Jameson, Baudrillard, Butler; see Bielskis 2005), "post-colonial theory" (Appadurai 1986; Guha and Spivak 1988; Spivak 1988). ${ }^{5}$

Such theories have proven popular, especially among those working with indigenous peoples (for example, Nelson 2009). Seldom recognized by either supporters or critics of the various streams of cultural thought, like Fischer, is the fact that cultural theory took the Parsonian division to heart in much the same way that anthropology did, though with very different results. In the most basic sense, cultural studies gained its critical foothold by recognizing that ordinary anthropological, sociological, historical, and economic work-the larger realm of Western socio-philosophical production that Parson had sought to organize-was itself part of the organization of meaning and meaning- making institutions in the supposedly rational Western societies. Taking Parson's formulation in a direction he did not perhaps anticipate or intend, cultural theory since the 1960s began with the premise that a central productive domain of Western culture was to be found in sociology, history, anthropology, economics (in addition to the old candidates like literature and philosophy)-the recognition that these fields were based in and around the production of meaning, difference, and organization, and were in conversation (to say the least) with the broader social, economic, and political processes of the societies in which they were embedded.

What bears thinking about today, though, is how seriously committed all of these various moves were to the cultural: how central "the remainder" had come to be to socio-philosophical self-understanding (Eagleton 2003), and how critical the "search for the primitive" (in the words of Stanley Diamond 1974) was to the past thirty years of academic progress outside of anthropology. ${ }^{6}$ Although different in purpose and orientation, any discussion of how the escalation of culture in academic introspection has accompanied the escalation of culture in the discourse of development and global capital is equally scarce. The result, as Sutton, Kuper, and others point out is that anthropologists have spent two decades running from a view of culture that has nonetheless pursued them, and pursued them both at their point of engagement with the field, and at the point of their engagement with the discipline.

In such a situation, then, what does it mean for an anthropologist (and for a Marxist anthropologist in particular) to say that culture remains central to the anthropological endeavor? How does one deal with the fact that pragmatic and theoretical versions of culture have converged so precisely in the realm of development-without giving in to the cynicism and retreat to scientism that Kuper and others advocate? $^{7}$

In Labrador the remainder has become the center in a different sense-indeed in a sense that would make a cultural studies approach decidedly uncomfortable. There local difference 
(indigeneity) has become a key element in the incorporation of a periphery into the political and economic center, as capital and the Canadian state seek to use elements of local indigenous claims to harness resources, labors, or whatever they find of value, into the national economy. In so doing, they reverse the value of local differences from those in the past that marked Labrador as a place they once cared little for, into the means for incorporating local difference in the larger set of differences that dominate the Canadian version of social order-one based on difference as means of legal and economic inclusion, where it once meant exclusion. It does so while simultaneously peripheralizing other, once more central places and peoples, from mining centers elsewhere in Canada or as far away as New Caledonia, to those larger publics with competing claims to those same national resources now made the private holdings of claimant groups (see Dombrowski 2002, 2007). These larger class dynamics are seldom mentioned by either Kuper and colleagues, or by Fischer and those in cultural studies. In such an instance, Inuit culture is at once pulled into the development dialect of encouragement/endangerment, and at the same time sunk amid a larger dialectic that renders culture increasingly irrelevant in other places. Mining companies move into one region as indigenous claims make land available for development that could not be harnessed otherwise (Dombrowski 2008), while abandoning other regions to the cascading that lands them amid the bottom billion-regardless of color, curiosity, or local creed.

In such a situation, any fixed notion of culture, either local or theoretical, remains far too discordant and compromised to serve any purely disciplinary, theoretical, or practical goal-incapable of resistance that is not at once collaboration, or representation that is not also potential-making differentiation. In simple terms, this is because the stuff of culture is deeply intertwined with social processes of inclusion and exclusion. This is why it can be mobilized as resistance and incorporation, truth and strategy, meaning and manipulation, and why I think that the naïve retreat to methodological honesty or purity by Kuper is as doomed as the pragmatic wholesaling of culture that he and others lament.

\section{Alienation and hope}

Stanley Diamond once argued that the hope for anthropology lays in the fact that anthropologists were the only people likely to be as alienated from their own societies as those they work among were becoming from theirs (Diamond 2004) - alienated from a set of social distinctions, political structures, and individual values and collective lifeways that they were never the less responsible for reproducing. ${ }^{8}$ It is the same feeling of estrangement that many indigenous people get when confronted with their own culture as such-as hopeless compromised and serving an ever shrinking portion of the community, or as largely irrelevant in a much broader race to a global bottom, for which there is yet to be any real alternative. Whether and to what extent such feelings can prompt people to look beyond the given meanings, orders, and choices of their lives remains a historical question, but there is little doubt that these more radical openings (made possible by the way contemporary development) fling perfect strangers into one another's lives.

This was the reason I went to Alaska-to look for people who were "against culture" (Dombrowski 2001), and I am doing the same in Labrador. Thus a major portion of my current research takes place among Inuit individuals and households displaced from Coast communities, recently or in the past, and amid those who remain on the Coast, and thus confront the local dynamics that make a future there increasingly precarious. Most of those who have left the Coast now live in mixed ethnic neighborhoods indistinguishable (but for the surrounding forest scenery) from the slums of Brooklyn that are close to my home. Cars rust on concrete blocks and basketball courts are strewn with broken glass. Government housing falls into rapid disrepair, but continues as the only available means 
of shelter. Alcoholism and drug use are rampant, and alcohol-affected children are common. People and goods move around in unpredictable ways, largely beyond any ordered vision of their supra-local flows.

The results of such processes come together in costly ways. A 2008 house fire in one such neighborhood in Happy Valley/Goose Bay killed a number of people, all Inuit, including children as well as adults. It was the result, inspectors concluded, of a stove fire in a house where "a party" had been going on for days. The final positions of the bodies suggested it was young children doing the cooking, but it took police several days to identify the victims, largely because so many adults and children in the community are regularly "missing" that the number of candidates for who might have been killed was huge. Yet the mixed communities of the same town have proven largely intractable to local authorities for many of these same reasons. Novel organizations, some church-based, some servicebased, some posing novel ethnic identities (the new Inuit-Metis are one example) have mushroomed, even in a place so far off the beaten track of global capital. These groups are not a movement, and not even a "new social movement" as it is sometimes phrased. But they do represent a "structure of feeling" around which emergent kinds of connection are taking place.

The approach that Diamond (2004) lays out asks us to use our sense of alienation-from a deeply compromised discipline with dubious motives for research; from those around us who fail to see the destructive ways of our society; from ourselves as people who struggle to see our research subjects as simply people in their own right-as a topic and guide to our position in the field. This is reflexivity, but in the nonsolipsistic sense-one that is not particularly concerned with the personal self-discovery of the ethnographer, but rather one that sees the experience of alienation as foundational to the anthropological situation, a situation that puts particular (anthropological) people in particular places at particular times, and simultaneously defines whom they meet there. The results of such a process should make it clear to us how and where we might wish to forge representational alliances with those we work among. This, of course, is multivocality, though not because "they" are somehow better at representing their own situations than "we" are, or because "they" have some intrinsic and privileged natural view. Rather, it is because, if we work among those on the margins, anthropological interaction and writing is likely to be one of the few areas where people who physically instance the remainder around which anthropology was founded have the opportunity to forge (not represent) a culture somehow different than the one that flung them, willy-nilly into our ethnographies.

In a sense, both of these efforts are what Diamond meant by the "search for the primitive" (1974). It is a search within ourselves, but only to the point that it raises questions about the alienation of the people we work among and how they came to be talking with us. Moreover, it is a search for people whose availability to ethnography is in some sense an indictment of the social processes that produce anthropology, past and present, and our search for them. Such a position places at the center of our inquiry the social conditions that produce anthropology and anthropologists, but only to the extent that these remain keys to the cultural processes of differentiation we seek to understand, counter, or enable, and the extent to which we seek a critical target capable of justifying our research praxis.

The social system that made anthropology remains a society at once soullessly in search of something meaningful, and yet one that seeks tirelessly to incorporate and grind to sameness that which stands outside of its particular logic. To the extent that cultural studies placed the primitive back at that center of our politics, we are in its debt. To the extent that we can produce a dialectical vision of culture and its making - a vision of anthropology as the product of a larger social strategy meant to tame the ungovernable, yet one that is empowered through this encounter to examine the very governing instincts that propel ethnography onward and outward, and in the process manage to prompt, not discover, the diverse ways of life we find (Sider 1987)—we have something to offer in re- 
turn. It is a vision of culture that requires for anthropology the ongoing discovery and coproduction of some Other, with the hope that the Other is produced not simply by our need for it, but rather as a check on the larger forces of which anthropology is symptom and realization. Anthropology has been rightly accused of such a search, but if our critics are right about the way culture works, I do not think we can do without it.

\section{Acknowledgments}

This article is the result out of three ongoing conversations. One is with Gerald Sider, whose ideas are apparent throughout, and who has argued for many years for a partisan anthropology. Another is with Randy Martin, who has pushed me to recognize the difference that an approach to the cultural has made, and might make. And one is with my co-editors at Dialectical Anthropology, especially Anthony Marcus, George Baca, and Ananth Aiyer. I alone am responsible for the rough mixing of what likely remains a different formulation of these ideas from that of these gifted thinkers. The original inspiration for writing came about in a long weekend of discussions with Gavin Smith, who provided the opportunity for doing this, and to whom much of the final shaping of the argument is owed.

Kirk Dombrowski is associate professor of anthropology at the CUNY Graduate Center and John Jay College, CUNY. His current research in Labrador focuses on a comparison of the social lives of Inuit residents of remote coastal communities and those former residents who have now moved to nearby metropolitan areas. Kirk's major field of interest is the intersection between global political economic forms and local, indigenous cultural production. He is the author of Against Culture (2001) and co-editor of Dialectical Anthropology (with Anthony Marcus and Ananth Aiyer).

E-mail: kdombrowski@jjay.cuny.edu.

\section{Notes}

1. Nowadays indigenous people(s) often hire lawyers, or forego the claims process altogether for privately negotiated three party agreements among themselves, surrounding states, and development forces who find usefulness in the "special status" they claim (Dombrowski 2002, 2008).

2. That is, seek to put into practice what has been called (somewhat wrongly) neoliberalism (see Dombrowski 2008).

3. That self-evidence was rooted in the presumed (and presumably equally self-evident) rationalism that was thought to govern Western lifeways. Thus the Parsons-Kroeber division of academic labor solidified in institutional and geographical terms a dawning recognition of a social and individual remainder, one that seemed resistant to explanations from economics, political science, and formalist sociology-and their accompanying acts of social engineering in the form of therapy, development, and modernization. Whether that remainder was itself alternatively rational, resistant, simply tragic, inevitably disappearing, or profound in its potential for critique is unresolved, as was the extent to which some element of the primitive stayed at the heart of those societies that produced the rational social sciences (Taussig 1987; see also Brown 1978).

4. Even the mainly Marxist elements within anthropology that sought to take up the critical potential of the Parsonian formulation could not adequately shed the evolutionist trappings left them by Marxism more generally, or resist the urge to domesticate the remainder with more formalist (albeit Marxian) terms (Nugent 2007; see also Vincent 1990).

5. This tradition has at times been at odds with anthropology, at times influenced by it, and at limited moments, even in continuing dialogue (again mainly with Marxist traditions; ScheperHughes 1995). Yet at this point, it is clear that over the last three decades cultural studies has largely come to displace anthropology as the key generator of theories of what Parson's had seen as the realm of the anthropological-culture in its social organization sense, as both medium and agent of foundational social processes of differentiation not encapsulated by the methods and theories of the formal social sciences (Eagleton 2003). 
6. Anthropology's engagement with the body of theory produced by cultural studies has been piecemeal and complex. Some found in it a challenge to anthropology as a science in the haloed, rationalist sense of the term (drawing on Foucault), which it was (see Segal and Yanagisako 2005). Others became fixed on the embeddedness of anthropology with larger political and economic processes (drawing on the writings of Edward Said) — the so-called handmaiden of colonialism argument (see Moore 1994). Still others focused on anthropology's dependence on particular cultural forms and technologies (drawing on Jacques Derrida and Roland Barthes) - texts, readers, and notions of authority and all the politics of reception that anthropology had previously ignored in constructing itself as a discipline (Abu-Lughod 1991; Clifford 1981). All of these were, not surprising, oversimplifications (at times drastically so) of the processes and histories involved, but the conclusions drawn are largely beyond doubt.

7. I do not suggest that anthropology ought to embrace the cultural in the cultural studies senseone that places radical alterity at the center of cultural inquiry. Anyone who tried to do so would likely find the field abandoned before they got there (Bérubé 2009). There is a widespread feeling among those in cultural studies that the movement has in effect run its course. Having shown social sciences and humanities to be part and parcel of a very Parsonian configuration of social life and subject determining institutions and attitudes, embedded within and dependent on a host of institutional, political, and economic configurations, inevitably and eternally so, there is little left there to do (short of joining some time-consuming and inevitably compromised political movement). That theory, in the cultural sense, is largely wrapped up and done.

8. Eagleton (2003) has argued that "the body," its fallibility and social dependency, ought to become our critical means of engagement and solidarity with those beyond us. I side with Diamond (2004), however, and see the basis of that solidarity as much more historically specific, and much more subjective in orientation, growing out of a process of alienation that is at once bodily, emotional, social, and specifically individual, which propels us to some other, whose sense of the same process is never quite our own.

\section{References}

Abu-Lughod, Lila. 1991. Writing against culture. In Recapturing anthropology, ed. Richard Fox, 137-62. Santa Fe, NM: School of American Research.

Appadurai, Arjun. 1986. Theory in anthropologyCenter and periphery. Comparative Studies in Society and History 28 (2): 356-61.

Barry, Peter. 2002. Beginning theory: An introduction to literary and cultural theory. Manchester: Manchester University Press.

Bateson, Gregory. 1972. Introduction: The science of mind and order. In Steps to an ecology of mind, xxiii-xxxii. Chicago: University of Chicago Press.

Bérubé, Michael 2009. Plenary Address. Cultural Studies Association Meetings, Kansas City Missouri, 17 April.

Bielskis, Andrius. 2005. Towards a postmodern understanding of the political: From genealogy to hermeneutics. London: Palgrave Macmillan.

Brown, Michael E. 1978. "Society against the State": The Fullness of the Primitive. October 6: 61-73.

Clifford, James. 1981. On ethnographic surrealism. Comparative Studies in Society and History 23: 539-64.

-1988. The predicament of culture. Cambridge: Harvard University Press.

Diamond, Stanley. 1974. In search of the primitive: A critique of civilization. London: Transaction.

Diamond, Stanley. 2004. Anthropology in question. Dialectical Anthropology 28: 11-32.

Dombrowski, Kirk. 2001. Against culture: Development, politics and religion in Indian Alaska. Lincoln: University of Nebraska Press.

- 2002. The praxis of indigenism. American Anthropologist 104 (4): 1062-73.

2007. Lifestyle and Livelihood: Culture Politics and Alaska Native Subsistence. Anthropologica: The Journal of the Canadian Anthropology Society 49 (2): 211-30.

- 2008. Reply: What's Changed (Since 1975)? Dialectical Anthropology 32 (1-2): 43-50.

Eagleton, Terry. 2003. After theory. New York: Basic Books.

Fischer, Michael. 2007. Culture and Cultural Analysis as Experimental Systems. Cultural Anthropology 22 (1): 1-65.

Graeber, David. 2001. Toward an anthropological theory of value: The false coin of our own desire. New York: Palgrave Macmillan. 
Guha, Ranajit, and Gayatri Spivak, eds. 1988. Selected subaltern studies. London: Oxford University Press.

Kuper, Adam. 2005. The reinvention of primitive society. 2nd ed. New York: Routledge.

Moore, Sally F. 1994. Anthropology and Africa: Changing perspectives on a changing scene. Charlottesville: University Press of Virginia.

Nelson, Diane M. 2009. Reckoning: The Ends of War in Guatemala. Durham, NC: Duke University Press.

Nugent, Stephen. 2007. Some reflections on anthropological structural Marxism. Journal of the Royal Anthropological Institute (N.S.) 13: 419-31.

Parsons, Talcott. 1937. The structure of social action. New York: McGraw-Hill.

Povinelli, Elizabeth A. 2002. The cunning of recognition: Indigenous alterities and the making of Australian multiculturalism. Durham: Duke University Press.

Scheper-Hughes, Nancy. 1995. The primacy of the ethical. Current Anthropology 36 (3): 409-20.

Segal, Daniel A., and Sylvia J. Yanagisako, eds. 2005. Unwrapping the sacred bundle: Reflections on the discipline of anthropology. Durham: Duke University Press.
Sider, Gerald. 1987. When parrots learn to talk and why they can't: Domination, deception and selfdeception in Indian-White relations. Comparative Studies in Society and History 29 (1): 3-23.

- 2003. Lumbee Indian histories: Race, ethnicity, and Indian identity in the Southern United States, Second Edition. Chapel Hill: University of North Carolina Press.

Spivak, Gayatri C. 1988. Can the subaltern speak? Speculations on widow sacrifice. In Marxism and the interpretation of culture, ed. Cary Nelson and Lawrence Grossberg, 271-313. Champaign: University of Illinois Press.

Sutton, Peter. 2009. The politics of suffering: Indigenous Australia and the end of the liberal consensus. Melbourne: Melbourne University Press.

Taussig, Michael T. 1987. Shamanism, colonialism, and the wild man: A Study in terror and healing. Chicago: University of Chicago Press.

Vincent, Joan. 1990. Anthropology and politics: Visions, trends, and traditions. Tucson: University of Arizona Press.

Widdowson, Frances, and Albert Howard. 2008. Disrobing the aboriginal industry: The deception behind indigenous cultural preservation. Montreal: McGill-Queens University Press. 